\title{
The importance of knowledge management systems for service industry companies operating locally and internationally
}

Marcin Soniewicki, Poznan University of Economics and Business, Poland, marcin.soniewicki@ue.poznan.pl

\begin{abstract}
This article aims to analyze the role of knowledge management systems (KMS) in knowledge processes taking place in particular types of service industry companies operating in Poland and checks the importance of these tools for such firms' competitiveness in the current globalized world. This study distinguishes among companies that operate only locally (in Poland), and those that are on particular levels of internationalization process. This article is based on quantitative research in which 381 service industry firms were examined. The analysis show relatively large differences in the intensity of KMS usage among particular groups of service industry companies. These tools are especially intensively used by information technology (IT) and telecommunication as well as transport companies, and, in turn, less intensively by real estate as well as hotel and restaurant enterprises. Analysis has also shown that intensity of KMS usage among firms on any level of internationalization is considerably higher than among those operating locally. However, the most important finding is that intensive use of KMS in service companies is associated with being more competitive than those using KMS less intensely, and this difference is statistically significant.
\end{abstract}

Keywords: Knowledge management, knowledge management systems, information technology, IT, service industry, internationalization, competitiveness

\section{Introduction}

Today, every kind of company is influenced by the knowledge based economy. It simply means that knowledge is the most important resource for creating competitive advantage (Brinkley, 2008; Powell \& Snellman, 2004). That is why companies need to develop effective knowledge management strategies. They are usually complex and consist of many elements. Most researches focused on social elements of knowledge management and its processes, as they are considered more important (Easterby-Smith \& Lyles, 2006; Paliszkiewicz, 2007). Nevertheless, this article concentrates on information and communication technologies used for knowledge management purposes, which in the literature are called knowledge management systems (KMS) (Šajeva, 2010). Moreover, this paper focuses on particular type of enterprises - service industry firm, as functioning of firms differ. That is why, particularly in terms of such specialized issues like KMS, it is better to compare enterprises as similar as possible, in order to get as valuable results as possible. 
This research tries to fill the narrow research gap that is the analysis of KMS and its particular elements' influence on competitiveness of service industry companies. In this matter, knowledge management as a whole and in various narrow aspects, have been quite broadly analyzed in the literature (Geisler, 2010; Johannessen \& Olsen, 2003). The importance of KMS or knowledge management information and communication technology (ICT) for competitive advantage of companies has also been previously analyzed in literature (Adams \& Lamont, 2003; Majors, 2010; Sher \& Lee, 2004), though not in so much detail, among various types of service industry companies. Such firms, despite being a part of one industry, are in fact very different, and it is due to the type of services they deliver. These require various actions and processes in order to be effective. This research tries to assess whether the intensity of KMS use is important element in this process and, if the answer to this question is positive, whether KMS are important for all kinds of service industry companies. It appears that such study has not been conduced, especially in Poland which is very specific market. This country became a free market economy in 1989 and joined the European Union in 2004 gaining access to European market. In these years, services became the most important part of Polish economy. And that is why the research question of this study is to check the intensity of KMSs' usage among various types of service industry companies and these tools' importance for such competitiveness of such firms.

This paper has three main goals - the first one is to analyze the intensity of KMSs usage among service industry companies. It includes checking the usage of those systems among firms offering particular kinds of services and the intensity of usage of particular KMS technologies. The second goal is to conduct a series of analyses on intensity of KMS usage among service industry companies operating locally and internationally. The third essential goal of the article is to look at the relation between KMSs' usage intensity and competitiveness of service industry companies. The perspective taken is to both look at service industry companies in general as well as focusing on those offering particular types of services. A very important analysis in this matter concentrates on relation between intensity of usage of particular KMS technologies and competitiveness of service industry enterprises.

\section{Literature Review}

The question of knowledge management in companies became a field which attracted interest around the beginning of the last decade of the $20^{\text {th }}$ century (Ahmed, Lim, \& Loh, 2002), and now many researchers considered it as one the most important concepts of our times (Boughzala \& Ermine, 2006). It appears to be a very complex issue. Literature provides many definitions. One of the better definitions appear to be provided by Paliszkiewicz (2007), who noted that knowledge management is a "systematic and organized process of locating, obtaining, transferring, using and saving knowledge, with the use of proper social elements and technologies, and with the purpose of improvement of companies' results" (p. 38). As noted, knowledge management uses technologies and social elements. The former is especially interesting as an initiating factor. Around 1990, a fast increase of usage of computers and the Internet was evident. This helped in bringing large amount of data to companies, even though it could not be immediately used. As a result, a development of KMS was emerging (Brdulak, 2005; Jashapara, 2006; Vera \& Crossan, 2005). 
The concept of knowledge management is sometimes associated with just KMS (Evans, 2005). Despite being a wrong approach, it underlines an importance of these systems in implementation of the concept (Martinez, 2010; Pasher \& Ronen, 2011). Lee, Kim, and Kim (2012) from South Korea considered KMS as the core of knowledge management. In the literature, in general, nobody opposes the thesis that KMSs are important when there is a need to analyze large groups of information and knowledge (Busch, 2008).

Nevertheless, there is also a number of problematic issues related to KMS. Firstly, it is difficult to support actions in the area of tacit knowledge with their help, as they rather concentrate on its explicit elements. However, there are exceptions, such as various, modern communication tools or those supporting group work like the example of British Petroleum (BP), which uses videoconferences to share experience of their best specialists (Handzic \& Zhou, 2005; Jashapara, 2006). Still, up to date, such tools are far from being perfect in the matter of tacit knowledge. Moreover, it is often encountered in business practices the problem consisting with concentration of companies on only one kind of such systems, and that usually does not bring the best results (Probst, Raub, \& Romhardt, 2004). Problems or lack of positive effects in the sphere of KMS are often caused not directly by these tools, but by lack of processes that those could support. Implementation of KMS is not synonymous with creation of necessary knowledge management processes (Martinez, 2010; Pasher \& Ronen, 2011).

Many researchers, such as Evans (2005), underlined that it is the human brain that is in the center of knowledge management and it is difficult to disagree. Without it, only information or data management can be discussed. However, taking into account the current competitive market, it is difficult to manage the knowledge fast enough in the company without KMS. This issue is called in the literature as KMS' paradox (Dąbrowski \& Gierszewska, 2005). It must be underlined that the most important feature and advantage of KMS is its speed. Moreover, KMS become more and more necessary because it is constantly becoming cheaper and able to quickly perform increasingly complex tasks (Soniewicki, 2015). In general, the use of all information technology tools influences the operation and results of companies. For example, there are research results suggesting that their use influences structure of companies' employment (Kaźmierczyk, 2012).

\section{Methodology}

This study is a result of the project financed by Polish National Science Center (no. 2011/03/N/HS4/00429). The publication is based on quantitative survey. The research was conducted in 2012 and the beginning of 2013 in Poland. The sample was selected from Kompass Poland database. For the study, a custom made, electronic surveying system was created and was the main research tool. Nevertheless, some questionnaires were sent by postal services as not all firms in the database allowed to be contacted electronically. There were more than 1200 companies analyzed, with 381 companies of them belonged to service industry. The detailed breakdown of service industry companies analyzed in the study, in terms of type of services offered, is presented in the Table 1. 
Table 1. The breakdown of service companies by the type of services they offer and their number in the analyzed sample

\begin{tabular}{|c|c|}
\hline The kinds of service industry companies & $\begin{array}{c}\text { No. of particular } \\
\text { kinds of } \\
\text { companies in the } \\
\text { sample }\end{array}$ \\
\hline IT and telecommunication services & 63 \\
\hline Hotel and restaurant services & 24 \\
\hline Real estate services & 17 \\
\hline Transport services & 28 \\
\hline Scientific, technical and other professional services & 112 \\
\hline Financial and insurance services & 17 \\
\hline Other services & 120 \\
\hline Total: & 381 \\
\hline
\end{tabular}

As Table 1 shows, six types of services have been distinguished. The other kinds of services are designated as "other services". There are 120 such companies in the analyzed sample - which is almost one third of the set. Very large share of the sample - 29.4\% - constitute companies offering scientific, technical and other professional services. Firms offering IT and telecommunication services make up a significant, but much smaller than the previous kinds of firms, element of the sample $-16.5 \%$. The remaining four groups of companies constitute $22.6 \%$ of the sample.

There are several KMSs available on the market. It is impossible to create their classification. Nevertheless, on the basis of literature, the typology of KMS has been constructed (Table 2).

Table 2. The typology of KMSs

\begin{tabular}{|c|c|}
\hline No. & Types of KMSs analyzed in the article \\
\hline 1 & $\begin{array}{r}\text { Basic information technologies } \\
\text { (Internet, e-mail, word processors, spreadsheets) }\end{array}$ \\
\hline 2 & $\begin{array}{c}\text { Data storage systems } \\
\text { (e.g. document storage, sharing and management systems, CRM, data warehouses) }\end{array}$ \\
\hline 3 & $\begin{array}{c}\text { Computer communication systems } \\
\text { (e.g. corporate portals, intranet, company forum, discussion groups) }\end{array}$ \\
\hline 4 & $\begin{array}{c}\text { Groupware/collaborative software } \\
\text { (comprehensive systems supporting team work) }\end{array}$ \\
\hline 5 & $\begin{array}{c}\text { Decision support systems, expert systems } \\
\text { (Business Intelligence, Executive Information Systems) }\end{array}$ \\
\hline
\end{tabular}

Source: Soniewicki (2015, p. 73) based on: (Alavi \& Tiwana, 2006, pp. 113-118; Paliszkiewicz, 2007, p. 66; Geisler \& Wickramasinghe, 2009, p. 13; Gierszewska, 2011, p. 180; Jemielniak \& Koźmiński, 2012, p. 306).

As Table 2 shows, five kinds of KMSs, according to their functions, have been distinguished. The first group consists of the most basic technologies - such as word processors or Internet. The second contains various systems dedicated for data storage in the companies. The third group is 
computer communication systems - for example intranet or corporate portals. The fourth group consists of groupware/collaborative software that are comprehensive systems supporting team work. The most advanced technologies belong to the fifth group - expert and decision support systems, which for example contains Executive Information Systems.

In the survey, respondents provided feedback about the use of particular types of distinguished systems in their companies with help of the 5-point Likert scale. Particular values in this scale meant: 5 - 'very intensive use'; 4 - 'intensive use'; 3 - 'average use'; 2 - 'low use'; 1 - 'we do not use' or 'I do not know the particular system'. The arithmetic mean was used to show the general intensity of use of KMS in a company, in groups of firms and in case of particular technologies. One of the important factors taken into account in this article is companies' international involvement and the form of this involvement. Six various forms have been distinguished. The number of companies, in the analyzed sample, using particular internationalization forms is presented in Table 3. It must be underlined that surveyed companies were allowed to choose several such forms.

Table 3. The number of companies using particular internationalization forms

\begin{tabular}{|c|c|}
\hline The internationalization forms used by analyzed companies & $\begin{array}{c}\text { No. of companies } \\
\text { in the sample }\end{array}$ \\
\hline No international involvement & 218 \\
\hline Import & 25 \\
\hline Indirect export (through domestic intermediaries) & 21 \\
\hline Subcontracting & 47 \\
\hline Direct export & 61 \\
\hline $\begin{array}{c}\text { Non-equity or equity cooperation } \\
\text { (licensing, franchising, joint venture) }\end{array}$ & 17 \\
\hline Foreign direct investment (FDI) & 22 \\
\hline
\end{tabular}

Table 3 shows that most of analyzed service industry companies are not involved internationally. Among those that operate abroad the most popular forms are direct export and subcontracting. Much less exploited are non-equity or equity cooperation, indirect export, foreign direct investment and import. Competitiveness of analyzed companies was analyzed with the method developed by Fonfara (2007). Respondents rated the competitiveness of their enterprise against their closest competitors in four areas: profit, value of sales, return on investment (ROI) and market share. They could choose five options: 1 - 'much worse', 2 - 'worse', 3 - 'more less the same', 4 - 'better', 5 - 'much better'. The statistical significance of differences in competitiveness of particular groups of companies were checked with use of Mann-Whitney U test using Statistical Package for Social Sciences (SPSS). This test was used, as no assumptions are required to the distribution of variable under test. In parametric tests normal distribution is assumed. 


\section{Research Results}

The results of empirical research have been divided into two parts. The first one concentrates on the intensity of KMS use by various types of service industry companies. The second part examines the competitiveness of particular service industry companies with various intensities of KMS use. The first analysis, presented in Table 4, shows the intensity of KMSs use among different types of service industry companies.

Table 4. The intensity of KMSs use among companies offering particular type of services

\begin{tabular}{|c|c|}
\hline The type of services offered by companies & $\begin{array}{c}\text { The } \\
\text { intensity } \\
\text { of KMS use }\end{array}$ \\
\hline IT and telecommunication services & 3.58 \\
\hline Hotel and restaurant services & 2.67 \\
\hline Real estate services & 2.51 \\
\hline Transport services & 3.26 \\
\hline Scientific, technical and other professional services & 3.02 \\
\hline Financial and insurance services & 3.08 \\
\hline Other services & 2.95 \\
\hline
\end{tabular}

On the basis of the results shown in Table 4, as far as the overall KMS use among service industry companies offering particular kinds of services is concerned, we can distinguish three groups:

○ High intensity of KMS use - IT and telecommunication services (3.58) and transport services (3.26);

- Medium intensity of KMS use - financial and insurance services (3.08) and scientific, technical and other professional services (3.02) and other services (2.95);

○ Low intensity of KMS use - real estate services (2.51), hotel and restaurant services (2.67).

It is not a surprise that companies offering IT and telecommunication services intensively use KMS, but in case of firms offering transport services it was rather not anticipated - it seems that it is not a very complicated type of service. Nevertheless, Polish transport companies are known as very competitive entities in the European Union. One of the reasons might be effective knowledge and KMS use. Another unexpected issue is a very low level of use of analyzed systems among companies offering real estate services as well as hotel and restaurant services. This might be caused by existence of many small hotels and restaurants as well as individual real estate agents in Poland that do not invest in such technologies.

The following analysis, in Table 5, presents more detailed data concerning the usage of particular types of KMSs by analyzed companies, and may bring more interesting and in-depth conclusions. 
Table 5. The intensity of use of particular KMSs types among companies offering specific type of services

\begin{tabular}{|c|c|c|c|c|c|}
\hline $\begin{array}{c}\text { Types of KMSs } \\
\text { Types of services } \\
\text { offered by companies }\end{array}$ & $\begin{array}{c}\text { Basic } \\
\text { information } \\
\text { technologies }\end{array}$ & $\begin{array}{c}\text { Data } \\
\text { storage } \\
\text { systems }\end{array}$ & $\begin{array}{c}\text { Computer } \\
\text { communication } \\
\text { systems }\end{array}$ & $\begin{array}{c}\text { Decision } \\
\text { Groupware/ } \\
\text { collaborative } \\
\text { software } \\
\text { systems, } \\
\text { expert } \\
\text { systems }\end{array}$ \\
\hline $\begin{array}{c}\text { IT and telecommunication } \\
\text { services }\end{array}$ & 4.79 & 3.89 & 3.56 & 3.17 & 2.49 \\
\hline $\begin{array}{c}\text { Hotel and restaurant } \\
\text { services }\end{array}$ & 4.17 & 3.17 & 2.67 & 1.96 & 1.38 \\
\hline Real estate services & 4.24 & 3.12 & 2.06 & 1.71 & 1.41 \\
\hline Transport services & 4.54 & 3.75 & 3.21 & 2.68 & 2.14 \\
\hline $\begin{array}{c}\text { Scientific, technical and } \\
\text { other professional services }\end{array}$ & 4.67 & 3.40 & 2.82 & 2.31 & 1.88 \\
\hline $\begin{array}{c}\text { Financial and insurance } \\
\text { services }\end{array}$ & 4.41 & 3.65 & 2.88 & 2.35 & 2.12 \\
\hline Other services & 4.43 & 3.31 & 2.78 & 2.35 & 1.85 \\
\hline
\end{tabular}

The results presented in Table 5 show that basic information technologies are intensively used, practically by service companies. Data storage systems are also very popular among service industry firms but much less than basic technologies. They are intensively used by enterprises offering IT, telecommunication, transport as well as financial and insurance services. Computer communication systems are quite intensively used by only IT and telecommunication services (3.56) and transport services (3.21). Their least intensive users are companies offering real estate services (2.06). Groupware and collaborative software are used with a bit higher than average intensity only by enterprises offering IT and telecommunication services. This kind of software is also used by transport services' firms, though still with below than average intensity (2.68). Companies offering other kinds of services use groupware and collaborative software with rather low intensity. The most advanced technologies - decision support systems and expert systems are rarely used in all kinds of service industry companies. Nevertheless, they are used more intensively in enterprises offering IT and telecommunication services, transport services, financial and insurance services, than among other service firms. Companies offering IT and telecommunication services as well as those offering transport services are characterized by the highest intensity of KMS usage in all categories. On the other hand, service firms offering hotel, restaurant and real estate services are characterized by the lowest intensity of examined technologies use also in all categories.

The following analysis concentrates on the overall KMSs usage among service industry companies with no international involvement and those using particular internationalization forms - Table 6. 
Table 6. The intensity of KMSs use among companies using particular internationalization forms

\begin{tabular}{|c|c|}
\hline The internationalization forms used by companies & $\begin{array}{c}\text { The intensity } \\
\text { of KMS use }\end{array}$ \\
\hline No international involvement & 2.93 \\
\hline Import & 3.02 \\
\hline Indirect export (through domestic intermediaries) & 2.85 \\
\hline Subcontracting & 3.09 \\
\hline Direct export & 3.29 \\
\hline $\begin{array}{c}\text { Non-equity or equity cooperation (licensing, franchising, joint } \\
\text { venture) }\end{array}$ & 3.71 \\
\hline Foreign direct investment (FDI) & 3.44 \\
\hline
\end{tabular}

As table 6 shows companies with no international involvement and those exporting through domestic intermediaries are characterized by the lowest intensity of KMSs usage. Nevertheless, the latter might also be considered as firms with no international involvement because these enterprises do not operate straightway internationally - they do not have direct contact with abroad. In general, companies with particular international involvement forms can be divided into three groups using the criterion of their intensity KMSs usage:

- The lowest intensity of KMS use - no international involvement and indirect export;

$\circ$ Medium intensity of KMS use - import, subcontracting and direct export;

$\circ$ The most intensive usage of KMSs - companies with more advanced internationalization forms - foreign direct investment and non-equity cooperation or equity cooperation.

The most intensive usage of KMS by companies operating internationally through non-equity or equity cooperation (licensing, franchising \& joint venture) can be explained by the fact that such entities probably cooperate with more experienced foreign entities which bring advanced KMS with them.

The more detailed investigation requires individual analysis of particular KMSs types, which is presented in Table 7. 
Table 7. The intensity of use of particular KMSs types among companies using specific internationalization forms

\begin{tabular}{|c|c|c|c|c|c|}
\hline $\begin{array}{l}\text { The internationalization } \\
\text { forms used by companies }\end{array}$ & $\begin{array}{c}\text { Basic } \\
\text { information } \\
\text { technologies }\end{array}$ & $\begin{array}{l}\text { Data } \\
\text { storage } \\
\text { systems }\end{array}$ & $\begin{array}{c}\text { Computer } \\
\text { communication } \\
\text { systems }\end{array}$ & $\begin{array}{c}\text { Groupware/ } \\
\text { collaborative } \\
\text { software }\end{array}$ & $\begin{array}{c}\text { Decision } \\
\text { support } \\
\text { systems, } \\
\text { expert systems }\end{array}$ \\
\hline $\begin{array}{c}\text { No international } \\
\text { involvement }\end{array}$ & 4.50 & 3.26 & 2.78 & 2.28 & 1.85 \\
\hline Import & 4.64 & 3.60 & 2.84 & 2.20 & 1.80 \\
\hline $\begin{array}{c}\text { Indirect export } \\
\text { (through domestic } \\
\text { intermediaries) } \\
\end{array}$ & 4.52 & 3.29 & 2.52 & 2.00 & 1.90 \\
\hline Subcontracting & 4.53 & 3.43 & 2.72 & 2.68 & 2.09 \\
\hline Direct export & 4.57 & 3.72 & 3.20 & 2.80 & 2.15 \\
\hline $\begin{array}{c}\text { Non-equity or equity } \\
\text { cooperation } \\
\text { (licensing, franchising, joint } \\
\text { venture) }\end{array}$ & 4.82 & 4.35 & 3.82 & 3.18 & 2.35 \\
\hline $\begin{array}{l}\text { Foreign Direct Investment } \\
\text { (FDI) }\end{array}$ & 4.73 & 4.09 & 3.41 & 2.59 & 2.36 \\
\hline
\end{tabular}

Basic information technologies are used very intensively by practically every type of service industry companies. This result was expected, as it is required by the world nowadays. Nevertheless, two most advanced internationalization forms - foreign direct investments and nonequity or equity cooperation - stand out. Moreover, one may also note intensive usage of data storage systems among mentioned kinds of enterprises. However, data storage systems are used above average (>3) among all groups distinguished in Table 7. This shows importance of such systems. Computer communication systems are used above average by service companies that operate abroad using non-equity or equity cooperation and foreign direct investment and direct export. Groupware / collaborative software are also used quite intensively only by service companies internationalizing through non-equity or equity cooperation (licensing, franchising, \& joint venture). Firms using direct export exploit this kind of technologies a bit below average (2.80), similarly as those using subcontracting (2.68) and foreign direct investment (2.59). Decision support systems are used, but in a little scope, by service companies with more advanced internationalization forms - non-equity or equity cooperation as well as foreign direct investment and to some extent direct export. The other kinds of analyzed service firms practically do not use them.

The result presented in Table 7 show that basic information technologies, and data storage systems are quite popular. Computer communication systems are also often used but rather by companies on higher levels of the internationalization process. The best chance for companies to distinguish from competitors would be using groupware/collaborative software or decision support/expert systems as they are rather rarely used technologies. 
The following analyses concentrate on competitiveness of service industry companies using KMSs with low or high intensity. The first of them is the most general - it compares the competitiveness level of all kind of service industry enterprises - Table 8 .

Table 8. The competitiveness level of service industry companies with low and high intensity of KMSs use

\begin{tabular}{|c|c|c|c|c|c|c|}
\hline $\begin{array}{l}\text { The intensity of } \\
\text { KMSs use }\end{array}$ & \multicolumn{2}{|c|}{$\begin{array}{l}\text { Low intensity }(<3) \\
\text { of KMSs use }\end{array}$} & \multicolumn{2}{|c|}{$\begin{array}{l}\text { High intensity ( } \geq \mathbf{3} \text { ) } \\
\text { of KMSs use }\end{array}$} & \multirow{2}{*}{ Difference } & \multirow{2}{*}{$\begin{array}{c}\text { p-value } \\
\text { (Mann- } \\
\text { Whitney U } \\
\text { test) }\end{array}$} \\
\hline $\begin{array}{l}\text { Type } \\
\text { of companies }\end{array}$ & Competitiveness & $\begin{array}{l}\text { No. } \\
\text { of } \\
\text { firms }\end{array}$ & Competitiveness & $\begin{array}{l}\text { No. of } \\
\text { firms }\end{array}$ & & \\
\hline $\begin{array}{l}\text { All service industry } \\
\text { companies }\end{array}$ & 2.93 & 168 & 3.24 & 213 & 0.32 & $<0.001 * * *$ \\
\hline
\end{tabular}

Table 8 shows that more service industry companies (213 firms $-55.9 \%$ of the examined) are characterized by high intensity $(\geq 3)$ of KMS usage. The other (168 firms $-44.1 \%)$ are characterized by low intensity $(<3)$ of their usage. Nevertheless, the most important conclusion from table 8 is that service industry companies with low intensity of KMSs usage are a bit less competitive than their closest competitors (2.93). On the other hand, entities with high intensity of knowledge examined systems usage are considerably more competitive (3.24) than their closest competitors. The difference in average competitiveness between these two groups of service business is 0.32 which is considerable and statistically significant. It must be underlined that apart from mentioned difference in competitiveness (0.32) the value below 3 means that companies are less competitive than their closest competitors and, respectively, above 3 means that they are more competitive than their closest competitors. This emphasizes the importance of KMSs in service industry companies. However, there is possible alternative explanation of observed difference. More competitive firms might have more financial resources and therefore employ more KMS. However, in order to effectively compete with them it is important to know what kind of tools they use and perhaps to employ them as well.

Table 4 showed that there are many differences in intensity of usage of KMS by service industry companies. That is why it is important to check competitiveness of particular types of service industry companies using knowledge managements systems with low and high intensity - Table 9.

Table 9 shows that among companies offering every kind of services those using more intensively KMS are more competitive. The differences in competitiveness - vary from 0.13 (among financial $\&$ insurance services) to 0.44 (among IT \& telecommunication services). Nevertheless, only in case of three types of service industry companies the differences in competitiveness are statistically significant. This is probably due to small number of examined entities in particular groups. The biggest difference in competitiveness between companies using KMSs with high and low intensity is among IT firms and telecommunication services. Moreover, one must note that those entities that use KMS with low intensity $(<3)$ have competitiveness value 2.77 what means that they are less competitive that their closest competitors. Entities using KMSs with high intensity have 
competitiveness value $3.22 \quad-\quad$ it means that they are more competitive than their closest competitors. What is more, the difference is statistically significant. Among real estate and transport firms - the differences are quite large but not

Table 9. The competitiveness level of companies offering particular types of services with low and high intensity of KMSs use

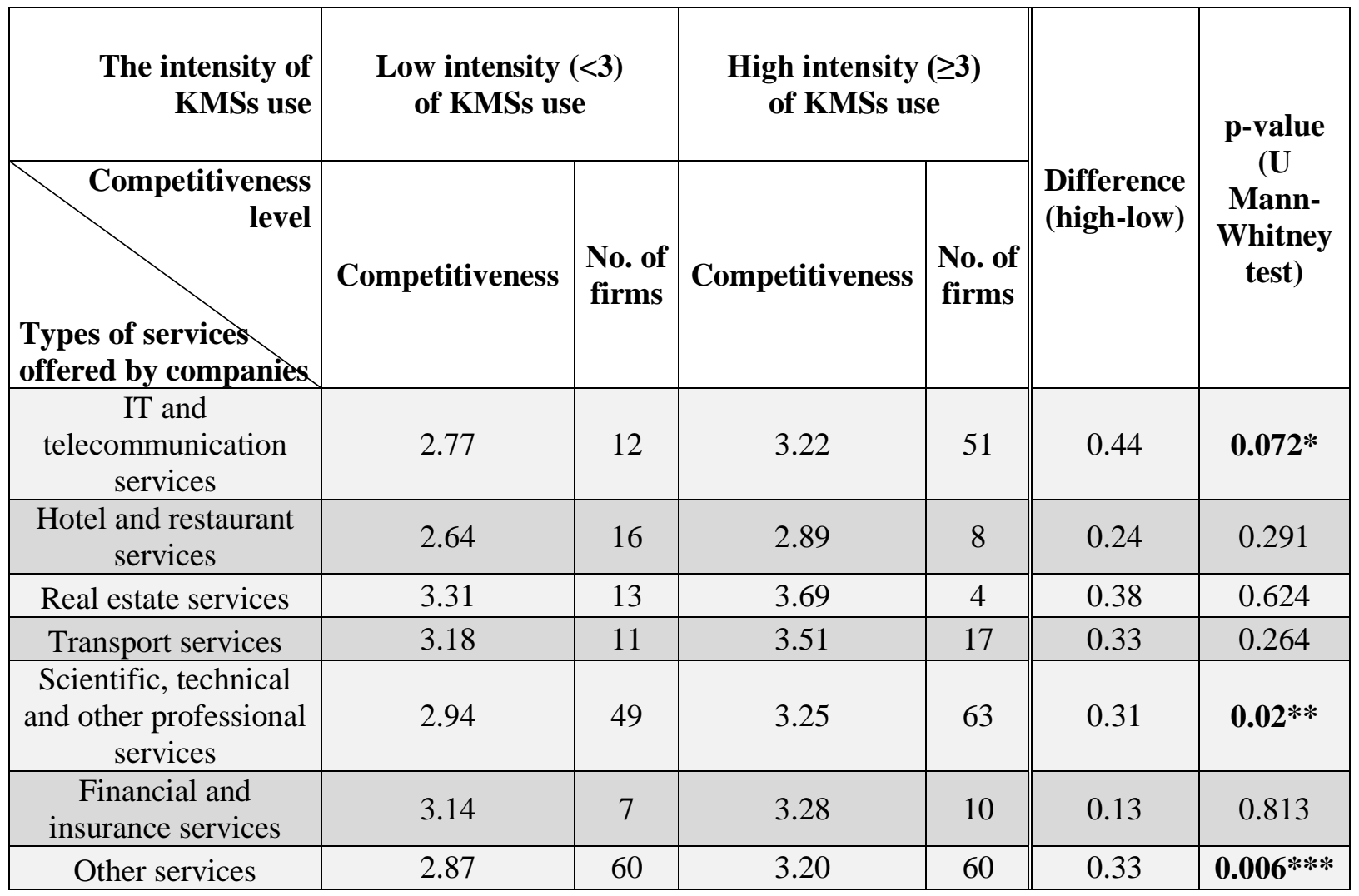

statistically significant. Probably because, as mentioned before, there were not so many firms examined in the research - 17 and 28 respectively. Similar problem - with small number of examined units - comes out in the case of firms offering hotel and restaurant services as well as financial and insurance services. In case of companies offering scientific, technical and other professional services, as well as other not classified elsewhere services, also quite large statistically significant differences are noticed in competitiveness.

The results presented in Table 9 clearly show that in case of firms offering IT and telecommunication services as well as scientific, technical and other professional services, competitiveness is much higher and statistically significant amid those entities that intensively use KMS. Among these groups the limit of three is also crossed and sets the boundary of being more or less competitive than closest competitors. This is understandable as such companies need to constantly create new services and innovations in order to survive, which usually require teamwork and effective, fast flow of knowledge. Today, KMS are irreplaceable in this. 
The following analysis concentrates on a different perspective - it investigates the competitiveness of all types of service industry companies using particular kinds of KMSs with low and high intensity - Table 10.

Table 10. The competitiveness level of service industry companies using particular KMSs with low or high intensity

\begin{tabular}{|c|c|c|c|c|c|c|}
\hline $\begin{array}{r}\text { The intensity } \\
\text { of particular } \\
\text { technology use }\end{array}$ & $\begin{array}{r}\text { Low intensity } \\
\text { of particul } \\
\text { technology }\end{array}$ & $\begin{array}{l}(<3) \\
\text { ar } \\
\text { ise }\end{array}$ & $\begin{array}{r}\text { High intensity } \\
\text { of particula } \\
\text { technology }\end{array}$ & $\begin{array}{l}(\geq 3) \\
\text { is } \\
\text { ise }\end{array}$ & & p-value \\
\hline $\begin{array}{l}\text { Types } \\
\text { of technologies }\end{array}$ & Competitiveness & $\begin{array}{l}\text { No. of } \\
\text { firms }\end{array}$ & Competitiveness & $\begin{array}{l}\text { No. of } \\
\text { firms }\end{array}$ & & test) \\
\hline $\begin{array}{l}\text { Basic information } \\
\text { technologies }\end{array}$ & 2.50 & 7 & 3.12 & 374 & 0.62 & $0.033 * *$ \\
\hline $\begin{array}{c}\text { Data } \\
\text { storage systems }\end{array}$ & 2.78 & 90 & 3.21 & 291 & 0.43 & $<0.001 * * *$ \\
\hline $\begin{array}{c}\text { Computer } \\
\text { communication } \\
\text { systems }\end{array}$ & 2.97 & 153 & 3.20 & 228 & 0.23 & $0.001 * * *$ \\
\hline $\begin{array}{c}\text { Groupware/ } \\
\text { collaborative } \\
\text { software } \\
\end{array}$ & 2.95 & 206 & 3.28 & 175 & 0.33 & $<0.001 * * *$ \\
\hline $\begin{array}{l}\text { Decision support } \\
\text { systems, expert } \\
\text { systems } \\
\end{array}$ & 3.04 & 276 & 3.29 & 105 & 0.25 & $0.002 * * *$ \\
\hline
\end{tabular}

The results presented in Table 10 show that all differences in competitiveness are statistically significant. The biggest difference can be observed among basic information technologies. However, almost all examined firms use them intensively. It appears that data storage systems and groupware/collaborative software are especially worth attention, due to the large differences in competitiveness between companies using them with high intensity and those using these systems with low intensity. In case of data storage systems the difference in competitiveness is greater, but $76.4 \%$ examined services firms already use these technologies intensively $(\geq 3)$. In case of groupware/collaborative software only $45.9 \%$ service industry companies use them intensively. Therefore, it can be a unique element, which use may help contemporary service industry companies in competing on the market. Moreover, it must be underlined that in both cases the statistical significance of the differences in competitiveness are very high ( $\mathrm{p}$-value $<0.001)$. The results also show that companies intensively using two remaining KMSs - computer communication systems and decision support systems/expert systems - are more competitive. It is especially worth to take a look at the latter - as not so many examined service industry firms use them intensively (only $27.6 \%$ ) and these firms are very competitive. 


\section{Conclusion}

This article contributes to the body of knowledge on several issues regarding KMS tools among Polish service industry companies. First, the results presented in the article show that the intensity of KMSs usage differs considerably depending on the type of services offered by companies. The highest intensity was observed among firms offering IT and telecommunication services. The lowest amid those companies offering real estate services. Basic information technologies, data storage systems and computer communication systems are used intensively by the most of service industry companies. Groupware /collaborative software is used intensively by $45.9 \%$ of the firms analyzed in the article and the most advanced decision support systems, expert systems by a bit more than one fourth of them. Second, service industry companies operating internationally use KMSs in general more intensively than similar firms operating only locally. One exception is indirect export, but such enterprises might also be perceived as not engaged in international operations as they do not have direct relations with foreign entities. KMSs are employed most actively by service firms using more advanced internationalization forms - non-equity or equity cooperation and foreign direct investment. Nevertheless, the most important contribution of this article concerns competitiveness of service enterprises. The result of analysis of all service firms shows that higher intensity of KMS use is associated with higher competitiveness.

Detailed analyses prove that the biggest difference in competitiveness between companies that use KMSs with high or low intensity is among firms offering IT and telecommunication services. A bit smaller differences were observed among real estate, transport, scientific, technical and other professional services as well as other unclassified kinds of services. Nevertheless, not all differences were statistically significant - probably due to the small number of examined entities in some groups. These conclusions are very important for companies offering IT and telecommunication services as well as scientific, technical and other professional services. In their case mentioned differences in competitiveness are statistically significant and also cross the limit of 3.0, which is the boundary of being more or less competitive in comparison to closest competitors. This is understandable, as such companies in order to survive need to constantly create new services, innovations, which usually require teamwork and effective, fast flow of knowledge. KMS are irreplaceable in this. Finally, the analysis conducted on the entire sample of service companies according to particular KMS tools has shown that usage intensity of any type of the analyzed KMSs is associated with competitiveness of service companies.

Further research in this area should concentrate on more detailed study of KMS in order to better understand how service industry companies use these tools and how these tools help them to increase competitiveness. Such study could be conducted with use of qualitative research methods. This article is based on quantitative research that brings considerable knowledge but also has limitations. The first of them is the fact that business strategy of analyzed companies has not been taken into account, just their use of KMSs and competitiveness level. Another issue that must be underlined is that this article proved only association between intensity of KMSs use by service industry firms and their competitiveness level. Nevertheless, the importance of KMS in creating competitive advantage for companies has been proved before, for example by Adams and Lamont (2003). The aim of this study was to analyze whether we can talk about similar phenomenon in case of various service industry companies in Poland. Moreover, considerable differences 
observed in the analyses constitute a very important argument for continuation of the analyses in this area, especially among some groups of service firms. Besides, service enterprises that compete with opponents that are currently more competitive, should know that their competitors use KMSs more intensively and without investing resources in this area it could be difficult to defeat them. For example, as Apple introduced Siri, Google immediately introduced Google Assistant, while Microsoft introduced Cortana.

\section{Managerial Implications}

The results presented in this article might be the source of several important inferences for managers of service industry companies. First of them is that all kinds of service companies should consider increasing intensity of the KMS use in order to enhance their competitiveness. They should especially pay attention to basic information technologies, data storage systems and groupware/collaborative software. Nevertheless, importance of computer communication systems as well as decision support systems/expert systems also should not be depreciated. Another inference concerns companies operating internationally. These firms use more KMS and they use them more intensively. Given earlier conclusion, company which wants to engage in internationalization process must take in to consideration the fact that it might encounter strong competitors with well developed KMS or rivals successfully cooperating with consulting service companies that effectively use KMS to support their customers. Third inference concerns the type of services delivered by a company. Among some types of service industry firms average use of KMS is very low. For example, among real estate services. High intensity of use of KMS might be useful tool for them when trying to increase company's competitiveness among, for example, entities offering real estate services. Nevertheless, it must be underlined that KMS must be implemented appropriately as well as the entity must be ready for them. Otherwise, such tools might only waste the money or even bring chaos to the company. Fourth inference is that among some kinds of service companies intensive use of KMS is crucial for competitiveness - for example in those offering IT and telecommunication services.

\section{Acknowledgements}

Article is a result of research project financed by Polish National Science Center, no. 2011/03/N/HS4/00429.

\section{References}

Adams, G. L., \& Lamont, B. T. (2003). Knowledge management systems and developing sustainable competitive advantage, Journal of Knowledge Management, 7(2), 142-154.

Ahmed, P. K., Lim, K. K., \& Loh, A. Y. E. (2002). Learning through knowledge management. Oxford, UK: Butterworth-Heinemann.

Alavi, M., \& Tiwana, A. (2006). Knowledge management: The information technology dimension. In M. Easterby-Smith \& M.A. Lyles The Blackwell Handbook of Organizational Learning and Knowledge Management. Oxford, UK: Blackwell Publishing, pp. 104-120. 
Boughzala, I., \& Ermine, J. L. (2006). Trends in enterprise knowledge management. London, UK: ISTE Ltd.

Brdulak, J. J. (2005). Zarzadzanie wiedza a proces innowacji produktu. Warszawa: Szkoła Główna Handlowa - Oficyna Wydawnicza.

Brinkley, I. (2008). The knowledge economy: How knowledge is reshaping the economic life of nations. London, UK: The Work Foundation,.

Busch, P. (2008). Tacit knowledge in organizational learning. New York, NY: IGI Publishing.

Dąbrowski, J., \& Gierszewska, G. (2005). Strategie Przedsiębiorstw a Zarządzanie Wiedza. Warszawa: Wydawnictwo Wyższej Szkoły Przedsiębiorczości i Zarządzania im.Leona Koźmińskiego.

Easterby-Smith, M., \& Lyles, M.A. (2006). Introduction: Watersheds of organizational learning and knowledge management. In M. Easterby-Smith \& M. A. Lyles, The Blackwell Handbook of Organizational Learning and Knowledge Management. Oxford, UK: Blackwell Publishing, pp. 1-15.

Evans, Ch. (2005). Zarządzanie Wiedza. Warszawa: Polskie Wydawnictwo Ekonomiczne.

Fonfara, K. (2007). Typologia zachowań przedsiębiorstw w procesie internacjonalizacji, Marketing i Rynek, PWE, No. 12, pp. 10-15.

Geisler, E., \& Wickramasinghe, N. (2009). Principles of knowledge management. Theory, practice, and cases. London, UK: M.E. Sharpe.

Geisler, E. (2010). Measuring the contributions of knowledge management systems to the strategic competitiveness of organizations: A review and a model. International Journal of Innovation and Technology Management, 7(2), 89-107.

Gierszewska, G. (2011). Zarzadzanie Wiedza w Przedsiębiorstwie-Modele, Podejścia, Praktyka. Warszawa: Oficyna Wydawnicza Politechniki Warszawskiej.

Handzic, M., \& Zhou, A. Z. (2005). Knowledge management. An integrative approach. Oxford, UK: Chandos Publishing.

Jashapara, A. (2006). Zarządzanie wiedza. Warszawa: Polskie Wydawnictwo Ekonomiczne.

Jemielniak, D., \& Koźmiński, A. K. (2012). Zarządzanie wiedzą. Warszawa: Wolters Kluwer Polska.

Johannessen, J.-A., \& Olsen, B. (2003). Knowledge management and sustainable competitive advantages: The impact of dynamic contextual training. International Journal of Information Management, 23, 277-289.

Kaźmierczyk, J. (2012). Information technology systems and their impact on the employment level in the Polish banking sector. Journal of Security and Sustainability Issues, 1(3), 187-195.

Lee, S., Kim, B. G., \& Kim, H. (2012). An integrated view of knowledge management for performance. Journal of Knowledge Management, 16(2), 183-203. 
Majors, I. (2010). ICT and knowledge management models for Ppromotion of SME's competitiveness. The International Journal of Technology, Knowledge and Society, 6(3), 173-184.

Martinez, A. R. M. (2010). Micro-bargaining as enhancer of knowledge management. A comparison between Mexico and Germany. Munchen und Mering, Germany: Rainer Hamp Verlag.

Paliszkiewicz, J. O. (2007). Zarządzanie wiedza w matych i średnich przedsiębiorstwachkoncepcja oceny i modele. Warszawa: Wydawnictwo SGGW.

Pasher, E., \& Ronen, T. (2011). The complete guide to knowledge management. A strategic plan to leverage your company's intellectual capital. Hoboken: John Wiley \& Sons, Inc.

Powell, W. W., \& Snellman, K. (2004). The knowledge economy. Annual Review of Sociology, 30, 199-220.

Probst, G., Raub, S., \& Romhardt, K. (2004). Zarządzanie Wiedza w Organizacji. Kraków: Oficyna Ekonomiczna.

Šajeva, S. (2010). The analysis of key elements of socio-technical knowledge management system. Economics and Management, 15, 765-774.

Sher, P. J., \& Lee, V. C. (2004). Information technology as a facilitator for enhancing dynamic capabilities through knowledge management. Information \& Management, 41, 933-945.

Soniewicki, M. (2015). The company's international competitive advantage - the role of knowledge. Warsaw, Poland: Difin.

Vera, D., \& Crossan, M. (2006). Organizational learning and knowledge management: Toward an integrative framework. In M. Easterby-Smith \& M.A. Lyles, The Blackwell Handbook of Organizational Learning and Knowledge Management. Oxford, UK: Blackwell Publishing, pp. 122-141.

\section{Author's Biography}

Marcin Soniewicki, Ph.D. is an Assistant Professor in the Department of International Marketing at Poznan University of Economics and Business in Poland. In his research, he concentrates on the role of knowledge management in the process of creating competitive advantage by modern enterprises. 